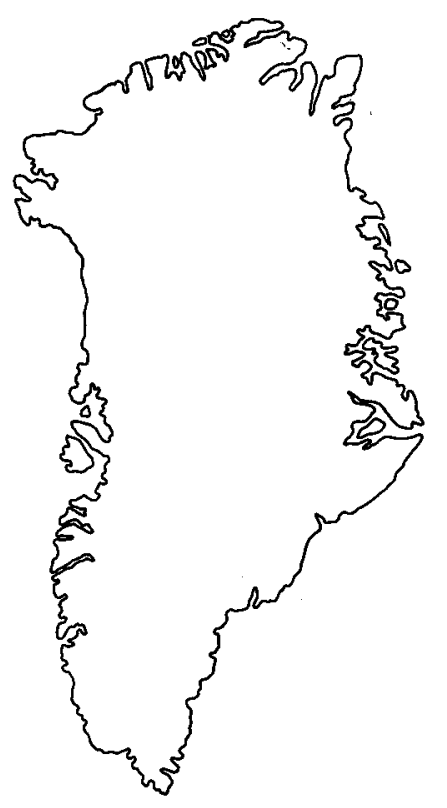

\title{
Some rugose corals from the Upper Permian of East Greenland
}

\author{
Jerzy Fedorowski
}

\begin{abstract}
Rugose corals are described from the Upper Permian Foldvik Creek Formation of Hold with Hope and Wegener Halvø, East Greenland. Specimens described from the same area by $\mathrm{H}$. W. Flügel in 1973 have been re-examined and revised. Among three species identified, Allotropiochisma birkenmajeri n.sp. belongs to a new genus, into which all Flügel's species of Amplexizaphrentis are included. All new species of Calophyllum introduced by Flügel are synonymised with Calophyllum profundum (Geinitz, 1842). The new subgenus Groenlandophyllum introduced by Flügel is not accepted. The life habits of corals and their adaptations to a muddy bottom are reconstructed and discussed.
\end{abstract}

J. F., Department of Geology, Laboratory of Invertebrate Palaeozoology, A. Mickiewicz University, ul. Mielzynskiego 27/29, 61-725 Poznan, Poland.

The following description of rugose corals from the Upper Permian of East Greenland is the second study on this subject since the work of Flügel (1973b). A study of a similar collection which is being conducted simultaneously by Dr. D. Weyer (oral communication) restricts to some extent the topics discussed herein. Consequently, those problems being examined by Dr. Weyer, e.g., the development of the naked proximal tip of the corallite in "Groenlandophyllum" and a discussion of the type species of the genus Calophyllum, are omitted from the present paper.

The fauna described here was collected in 1976 by Professor K. Birkenmajer in the course of field work undertaken under the auspices of the Geological Survey of Greenland (GGU). A summary of Upper Permian stratigraphy in East Greenland is given by Birkelund \& Perch-Nielsen (1976). The corals were obtained from the Foldvik Creek Formation of Late Permian age. Locality information (fig. 1) is given below:

GGU collections 229902, 229903. Profilbjerg, East ridge, Wegener Halvø, 500-505 m above sea level, Posidonia Shale Member;

GGU collection 229904. Profilbjerg, East ridge, Wegener Halvø, 505-508 m above sea level, Productus Limestone Member;

GGU collection 230063. Freboldbjerg, Hold with Hope, $260 \mathrm{~m}$ above sea level, Martinia Limestone Member. 


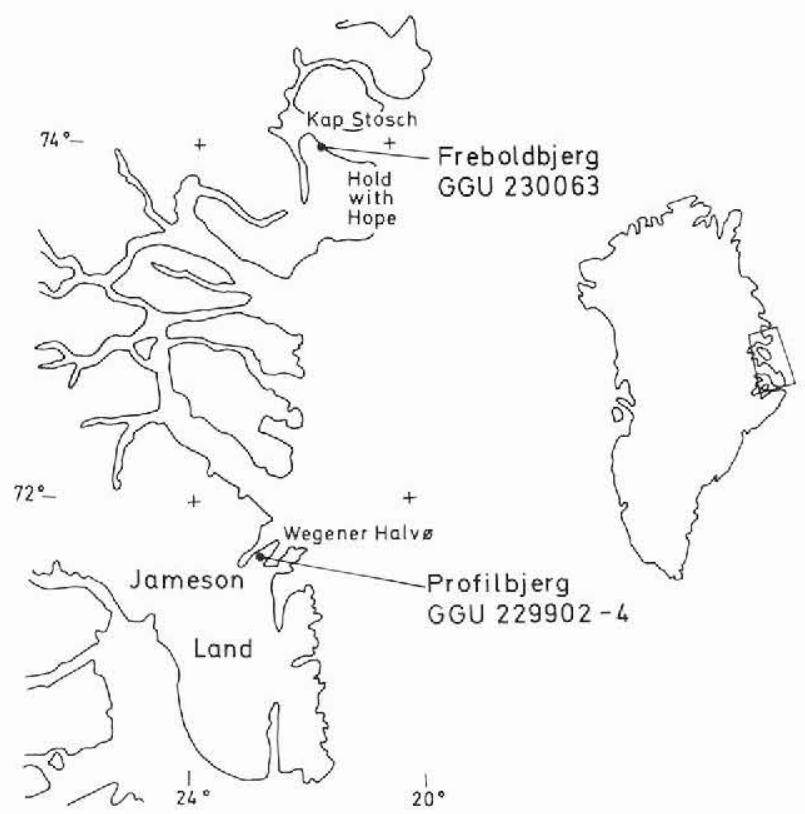

Fig. 1. Locality map.

All specimens described by Flügel (1973b) and restudied here came from the Productus Limestone Member. The distribution of the available material thus permits a comparison of corals from two different facies, which proves to be especially important in the case of Calophyllum profundum. Specimens from the Posidonia Shale Member are mostly preserved in calcite, but parts of individual corallites may be silicified or pyritised, or both. In consequence, it has been necessary to retouch the majority of the photographs of specimens figured here.

\section{Systematic description}

Order Rugosa Milne-Edwards \& Haime, 1850

Family Polycoeliidae Roemer, 1883

Genus Calophyllum Dana, 1846

Remarks. The genus Calophyllum has been the subject of so much discussion that any more general comment seems unnecessary. Thus, only opinions connected directly to the present collections are introduced.

In contrast to Flügel (1973b), the subdivision of the genus Calophyllum proposed by Schindewolf (1942) is not followed here. Consequently, the subgeneric name Tetralasma is not used. This is in part because the latter subgenus was distinguished on the basis of a single, incomplete specimen (only two sections made across the calice are present), but mainly because no constant, quantitative characters are available for employment. The underdevelopment of metasepta and counter-lateral protosepta, the only quantitative subgeneric character pointed out by Schindewolf, has proved to be inconstant when the more complete material available at present is studied. 
The subgeneric name Groenlandophyllum Flügel, 1973, is not accepted here. The major diagnostic character of this subgenus, i.e., the naked tips of specimens (Plate 4, fig. 5), is present in all the better preserved specimens in the collection studied here, independent of whether their internal morphology otherwise suggests 'Tetralasma' or 'Groenlandophyllum'. Similar naked tips have already been described in unrelated groups of rugosans (e.g. Birenheide \& Soto, 1977). However, a detailed discussion of this problem is currently under preparation by Weyer and the topic is not further persued.

Ivanovsky (1972) discussed the considerable internal variability of $C$. profundum (Geinitz, 1842), the type species of the genus Calophyllum and several problems connected with the genus in question. Ivanovsky $(1972$, p. 6, Table 1) stated that "metasepta can be inserted in all six sextants" which is in absolute disagreement with all earlier observations by other students of the family Polycoeliidae, as well as with his own illustrations. In none of specimens illustrated by Ivanovsky is there a single major septum inserted between the counter and counterlateral septa. All septa are clearly inserted in quadrants as they always are in the rugose corals. The specimens here described show that a single minor septum or pair of minor septa adjacent to the counter septum may occasionally, and for only a short period of development, penetrate a corallite lumen, although other minor septa are absent from the lumen. Similar minor septa were most probably interpreted by Ivanovsky as newly inserted major septa in 'sextants'. Ivanovsky's opinions concerning 'sextants' versus 'quadrants' of septa in rugose corals (Ivanovsky, 1972, p. 6) and his interpretation of Kunth's (1869) rule (Ivanovsky, 1972, p. 9) are also misleading, as is the term 'fibro-normal trabeculae' (Ivanovsky, 1972, p. 8). The term 'fibro-normal fine structure' was introduced by Kato (1963) for septa interpreted as non-trabecular. Thus, these two terms (trabecular and fibro-normal) should in no way be united.

\section{Calophyllum profundum (Geinitz, 1842)}

Plates 1-2; Plate 3, figs 1, 2, 6, 7;

Plate 4, fig. 5; Fig. 2.4

1842 Cyathophyllum profundum Geinitz, p. 579.

1941 Polycoelia baytuganense Soshkina in Soshkina et al., p. 69. (cum synon.).

1942 Polycoelia (Polycoelia) profunda (Geinitz); Schindewolf, p. 67. (cum synon.).

?1942 Polycoelia (Polycoelia) rossica Schindewolf, p. 80.

1942 Polycoelia (Polycoelia) compressa Ludwig; Schindewolf, p. 72.

1972 Calophyllum profundum (Germar in Geinitz); Ivanovsky, p. 5.

1973a Calophyllum profundum (Geinitz); Flügel, fig. 3.

1973b Calophyllum (Tetralasma) permica Flügel, p. 6.

1973b Calophyllum (Tetralasma) punctata Flügel, p. 8.

1973b Calophyllum (Tetralasma)? micron Flügel, p. 10.

1973b Calophyllum (Groenlandophyllum) teicherti Flügel, p. 12.

1973b Calophyllum (Groenlandophyllum) nodosum Flügel, p. 15.

Individual variation. The extraordinarily wide variation shown by $C$. profundum was recently discussed by Ivanovsky (1972) in Kazanian specimens from the Russian Platform, and by Weyer (oral communication) among representatives of this species from the west European Zechstein. The specimens discussed here have added to our knowledge of this 


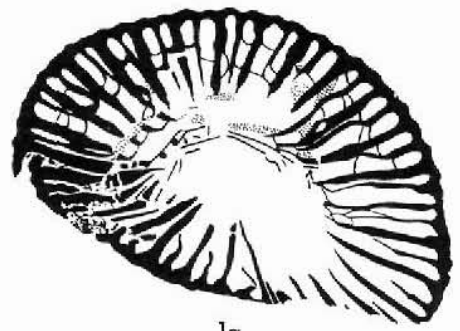

la

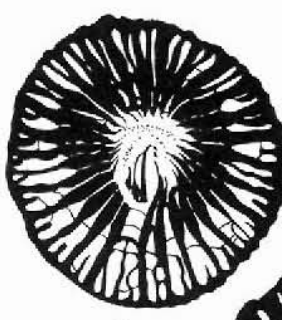

lc
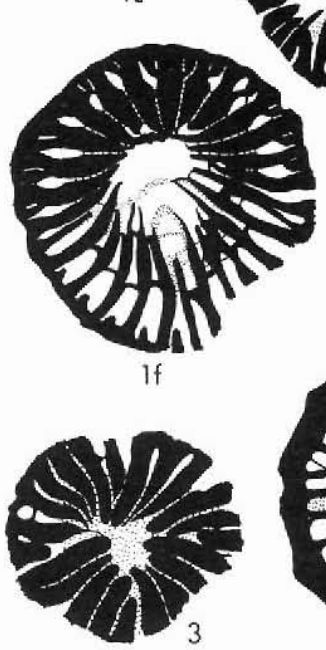

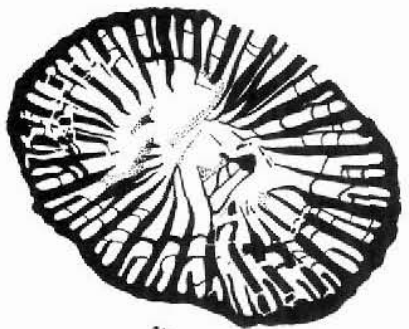

$1 \mathrm{~b}$

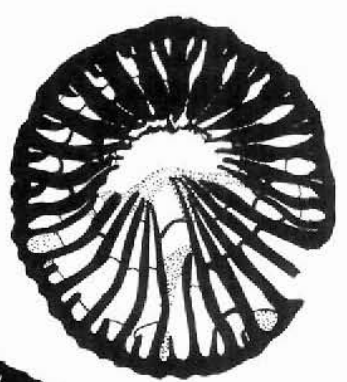

le

$2 b$
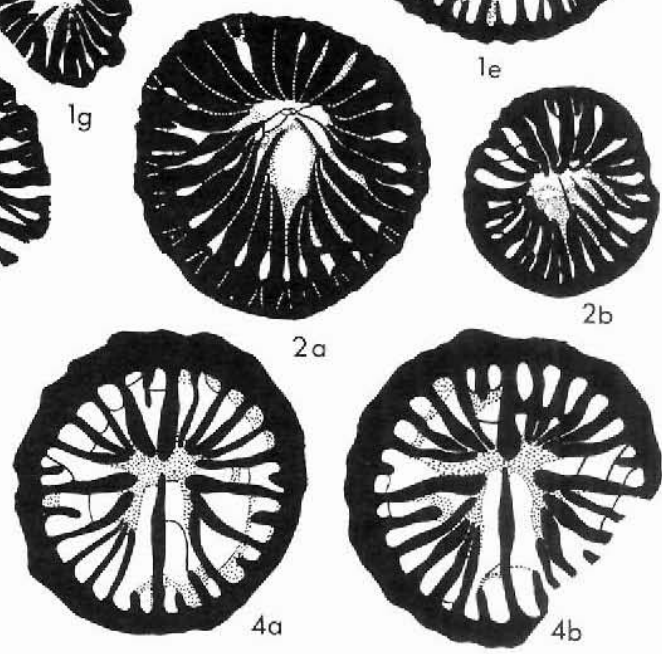

Fig. 2. Permian rugose corals from East Greenland. 1, Allotropiochisma birkenmajeri n.sp. holotype, MGUH 15.944 from GGU collection 230063. Hold with Hope, Martinia Limestone Member, Foldvik Creek Formation, Upper Permian. a, b, ephebic stage, $\times 2$; c, d, late neanic stage, $\times 2$; e, f, neanic stage, $\times 3.3 ; \mathrm{g}$, early neanic stage, $\times$ 3.3. 2, Allotropiochisma longiseptata (Flügel, 1973). MMH 11.948, holotype. Kap Stosch, Productus Limestone Member, Foldvik Creek Formation, Upper Permian. a, b, neanic stage, $\times 3.3$. Sections not illustrated by Flügel, (1973b). 3, Tachylasma rhizoides Soshkina, 1925. MMH 11.943. Locality as above. Neanic stage, $\times 3.3$. Section illustrated by Flügel (1973b, fig. 13A). 4, Calophyllum profundum (Geinitz, 1842). MMH 11.933, holotype of C. (G.) nodosum Flügel, 1973. Locality as above. a, b, ephebic stage. $\times 3.3$. Section $4 \mathrm{~b}$ illustrated by Flügel (1973b, text-fig. 7C). 
variation in several other characters. Most of the species came from the Posidonia Shale Member, from a single uniform environment (see discussion, below), thus considerably lowering the number of external factors influencing the variation.

It has to be pointed out that very little variability was observed in:

1. Ontogeny; all specimens observed (about 30) show major septa which are thickened, arranged zaphrentoidally and joined at the corallite axes. Cardinal, counter and alar protosepta dominate, but they are never so prominent as to suppress other major septa (Plate 1, figs 1d, 2d, 3e, f, 4c, 5b, 6d; Plate 2, figs 2b, 3f, 7c).

2. The acceleration of increase in the number of septa in the counter quadrants; the latter quadrants always occupy more than half of a corallite lumen.

3. Almost invariable absence of minor septa in the corallite lumen. Only in two of the specimens studied were a pair of septa (Plate 2, fig. 5) or a single septum (Plate 2, fig. 7b) found in the vicinity of the counter septa. Several minor septa were also seen to be temporarily elongated in the holotype of Calophyllum (Groenlandophyllum) nodosum Flügel (Plate 2, fig. 1a; fig. 2.4a). Septal wrinkles corresponding to minor septa were observed in all better preserved specimens, however.

The transformation from the neanic to the early ephebic morphology caused the first differentiation within the observed specimens: in one group calices are so deep as to almost reach the neanic arrangement of septa (Plate 1, fig. 2). More prominent differentiation of the length of the major septa took place only in the calices or just beneath them. Calophyllum (Tetralasma) punctata and C. (T.)? micron of Flügel (1973b) belong to this group of specimens.

In the second group, calices are also deep, but a period of growth is present beneath calices showing clearly ephebic morphology. Variability in this group is more complex. Specimens possessing major septa which are more thickened in the counter than in the cardinal quadrants are most common. Calophyllum (Groenlandophyllum) teicherti Flügel, 1973, belongs here. This central group of specimens exhibits further subdivision into small (Plate 1, figs 4, 5, 7, 8) and medium sized specimens (Plate 1, fig. 6; Plate 2, figs 4, 5, 6) in which a successive reduction towards completely free septa can be observed. There is also a fork leading from this central group towards $C$. $(G$.) nodosum Flügel, 1973 (Plate 1, fig. 3; Plate 2, fig. 2).

In addition to the aforementioned groups, there are also individual specimens in which particular structures changed several times during their ephebic growth period, thus being comparable to $C$. (T.) permica, $C$. (G.) teicherti, and $C$. (G.) nodosum although also showing additional morphological features (Plate 2, fig. 3). Some specimens show an extraordinary thickening of the protosepta, especially of the counter and alar ones. These protosepta may either stay prominent and thickened high in the calice (Plate 1, fig. 1) or may appear only at certain stages of development (Plate 1, figs 3c, d; Plate 2, fig. 2b, 3c). In a single specimen from the Posidonia Shale Member, a clear domination of four protosepta, arranged in an almost regular cross, was observed (Plate 3, fig. 1).

In the great majority of the specimens studied, the cardinal septa remain elongated also in the calice. In some, however (Plate 1, fig. 2a in this paper; fig. 2C in Flügel, 1973b), the cardinal septa can be distinctly shortened. This feature is not connected to any particular kind of earlier morphology, and is therefore not stressed here as a character of any importance for taxonomy.

Specimens collected from limestones are rare and, except for a single one (Plate 3, fig. 
2a-2c), are preserved only as calices showing 'Tetralasma' morphology (Plate 3, figs 6, 7). Being much larger than the specimens collected from shales, the more complete specimen collected from limestones (Plate 3, fig. 2) does not show differences in morphology exceeding the intraspecific variation. The large dimensions of all the limestone specimens perhaps reflect more favourable conditions for coral development during periods of limestone deposition than were present during deposition of the shales. No information as to the morphology (epithecate or naked) of the tips is provided by the specimens from limestone.

Remarks. As has been briefly pointed out above, all species of Calophyllum introduced by Flügel (1973b) can be closely compared with particular groups of specimens distinguished herein as individual variants of $C$. profundum. Such a wide understanding of the latter species is supported by:

1. The considerable variation within specimens coming from the western European Zechstein, the type stratigraphic level for this species (Weyer, oral communication) and by the even greater variability of Kazanian specimens (Ivanovsky, 1972).

2. All morphological differences discussed herein occur in specimens coming from the same facies, the same geological horizon and most probably from a single population.

3. The presence of so many intermediate specimens that any constant interspecific boundary cannot be established.

Re-examination of Flügel's (1973b) specimens shows that:

1. The orientation of his fig. $2 \mathrm{C}$ is incorrect. The distinctly shortened cardinal septum is in fact placed on the left side of this figure, which should be turned $90^{\circ}$ to the right in order to be comparable with the other two. The specimen possesses a very deep calice (approximately $20 \mathrm{~mm}$ ) and bears abundant, small knobs on its surface. The knobs, although connected to the growth rings, are arranged also in vertical rows.

2. Several specimens, e.g. the holotypes of $C$. (T.) permica, $C$. (G.) teicherti and $C$. (G.) nodosum possess calices which are deeper on the cardinal septum side. This is also true for all specimens described herein.

3. The temporary appearance of several minor septa in the lumen of the holotype of $C$. (G.) nodosum (Plate 2, fig. 1a; fig. 2.4a) is especially noteworthy. Although not present in the neanic stage, as in C. rossicum (Schindewolf, 1942), they show the potential opportunity for the population under discussion to develop this character. The orientation of Flügel's (1973b) figs 7A, B of the holotype of $C$. (G.) nodosum is incorrect, and should be turned $90^{\circ}$ to the right in order to be compared with fig. $7 \mathrm{C}$.

Ivanovsky (1972) studied a very large collection from the Lower Kazanian deposits of the eastern side of the Russian Platform and identified over 500 specimens as $C$. profundum. He placed C. rossicum in synonymy with the former species and stated (Ivanovsky, 1972, p. 8) that Schindewolf's holotype came from Kamyshela Village vicinity, i.e. from one of five collecting localities of Ivanovsky himself. There are two characters which distinguish the holotype of $C$. rossicum from other previously described populations of $C$. profundum:

1. More numerous major septa; this is a character of lesser importance because similar examples are known to occur as extreme variants of $C$. profundum.

2. Presence of minor septa inside the corallite lumen - a character never reported as constant for $C$. profundum. Ivanovsky did not discuss this character in detail, but the neanic 
stages of corallites illustrated by him represent both conditions; specimens with minor septa are illustrated by Ivanovsky (1972) on Pl. 3, figs 4a, b, 6v; Pl 4, fig. 2b; and without minor septa as Pl. 2, figs $2 \mathrm{~b}$, v; Pl. 4, figs $1 \mathrm{v}$, 6b. It seems most probable that Schindewolf's holotype represents the extreme development of this character, but this supposition needs additional study for verification.

Occurrence. Western and central Europe, Zechstein, Upper Permian; USSR (Russian Platform), Lower Kungurian, Upper Permian; East Greenland, Foldvik Creek Formation, Upper Permian.

\author{
Family Tachylasmatidae Grabau, 1928 \\ Genus Tachylasma Grabau, 1922 \\ Tachylasma rhizoides Soshkina, 1925 \\ Plate 3, figs 3-5; Fig. 2.3
}

1925 Tachylasma rhizoide Soshkina, p. 85.

1928 Tachylasma aster Grab. var. rhizoides Soshkina; Soshkina, p. 364.

1928 Tachylasma aster var. cylindroconica Soshkina; Soshkina, p. 365.

1941 Tachylasma aster var. rhizoides Soshkina in Soshkina et al., p. 59.

1941 Tachylasma aster var. cylindroconica Soshkina in Soshkina et al., p. 62.

1973b Cryptophyllum (Tachylasma) ? irregulare Flügel, p. 22.

1973b Lytvolasma (?) sp. cf. L. geinitzi (Toula, 1875); Flügel, p. 30.

Material. A single, incomplete specimen with only the neanic stage preserved and the restudied material of Flügel (1973b). Specimens of Soshkina $(1925,1928)$ and Soshkina et al. (1941), restudied earlier, were also considered.

Diagnosis. Tachylasma with n:d ratio 1.5-1.8, maximum 34:22; four protosepta come very close to the corallite axis with alars dominating; cardinal and counter septa shortened early in ontogeny; metasepta often asymmetrically developed.

Remarks. The morphology of this species was adequately described by Soshkina et al. (1941) and will not be repeated. It only has to be stressed that the dissepiments mentioned by Soshkina et al. (1941, p. 60) as present in this species are not developed. It can be presumed that sections of peripheral tabulae were interpreted as dissepiments. Soshkina's specimens of both, T. aster rhizoides Soshkina, 1925 and T. aster cylindroconica Soshkina, 1928 show wide variability in most of their morphological characters and dimensions. These differences intergrade and/or may be repeated in particular subspecies. The presence of a smoother surface, the only individual character of $T$. aster cylindroconica, seems inadequate even for subspecific distinction.

The holotype of Cryptophyllum (Tachylasma)? irregulare Flügel, 1973 was illustrated by Flügel (1973b, fig. 10) only in the neanic stage. The presently reillustrated neanic stage of this specimen (Pl. 3, fig. 3c-f) shows that the major septa and especially the four protosepta are more rhopaloid in character. The ephebic stage, cut and illustrated herein (Pl. 3, fig. 3a-b), shows four protosepta of considerable length which almost meet at the corallite axis, the dominant role of the alar protosepta, the reduction in thickness of all septa, asymmetrical arrangement and development of major septa and the well developed minor septa. All these characters can easily be found in Soshkina's specimens. 
The specimen of Lytvolasma(?) sp. cf. L. geinitzi (Toula, 1875) of Flügel (1973b) shows characters similar to those of the specimen discussed above. Its youngest (Plate 3, fig. 2.3) and morphologically most advanced sections (Plate 3, fig. 4b), as well as the calice (Plate 3, fig. 4a), also show the main characters in common with $T$. rhizoides. It has to be noted, however, that the specimen is immature and should be compared with immature samples or sections.

The specimen recently collected by Professor Birkenmajer (Plate 3, fig. 5) differs slightly from the other Greenland specimens in possessing a more symmetrical arrangement of septa in the quadrants, and in the more prominent development of the metasepta adjacent to the cardinal septum. These differences, observed in the neanic stage, do not seem taxonomically important, especially in a species so variable as the one discussed.

Only two other species of Tachylasma, i.e., T. aster Grabau, 1928, and Pentaphyllum (Tachylasma) variabile Schindewolf, 1941, can be closely compared with $T$. rhizoides Soshkina. $T$. aster differs in its much better development of minor septa, longer counter septum and symmetrical arrangement of the less numerous but thicker major septa. $P$. (T.) variabile differs first of all in possessing a cardinal septum which is elongated for a considerable time in ontogeny and in the symmetrical arrangement of its septa. These differences are small and synonymy of the latter species with $T$. rhizoides seems likely.

Occurrence, USSR (Ural Mountains), Artinskian, Lower Permian; East Greenland: Kap Stosch, Productus Limestone Member, Upper Permian; Hold with Hope, Foldvik Creek Formation, Martinia Limestone Member, Upper Permian.

\section{Family Hapsiphyllidae Grabau, 1928 \\ Genus Allotropiochisma n.gen.}

Type species. Amplexizaphrentis longiseptata Flügel, 1973.

Derivation of name. Named after its similarity to Allotropiophyllum and Baritichisma.

Diagnosis. Medium to large solitary corals without dissepimentarium; protosepta at early neanic stage slightly elongated; major septa are withdrawn early from the corallite axis, arranged allotropiophylloidally at least in some stages of ontogeny; cardinal septum shortened; cardinal fossula bordered by two septa, inconspicuous; fine structure of septa trabecular and/or multitrabecular.

Remarks. Characters of the new genus pointed out in the diagnosis form a mixture of features which can either be found in, or be compared to, several Permo-Carboniferous genera. The seemingly most similar Lower Carboniferous genus, Amplexizaphrentis Vaughan, 1906, differs from the new genus in possessing a persistent zaphrentoidal neanic stage with major septa joined in a corallite axis and grouped in quadrants with well developed pseudofossulae. The allotropiophylloid arrangement of the septa in the cardinal quadrants, commonly rhopaloid character of septa in the counter quadrants and a slight domination of protosepta, all features characteristic for the new genus, have never been found in either the type species of Amplexizaphrentis or in other species undoubtedly belonging to this genus.

Bradyphyllum Grabau, 1928, in common with Allotropiochisma n.gen., shows slightly 
rhopaloid septa, at least in some stages of growth. In addition, both possess axial areas free of septa (the new genus may not in some species) and thickened septa in the neanic stage. Allotropiochisma n.gen. differs from Bradyphyllum in not developing the calophylloid neanic stage, in the early shortening of major septa, the allotropiophylloid instead of zaphrentoid arrangement of septa in the cardinal quadrants and in the differentiation of thickness of septa in the quadrants; the last character may not be developed in the new genus, however.

Allotropiophyllum Grabau, 1928, is one of the two genera most closely related to the new genus. This is first of all seen in the arrangement of septa in the cardinal quadrants, in the lack or underdevelopment of pseudofossulae, and in the development of septa in the counter quadrants. The latter are always shorter than those in the cardinal quadrants and are often in touch by being slightly or distinctly rhopaloid in character. The marked shortening early in ontogeny of septa with slightly elongated protosepta, the commonly observed differentiation in thickness of major septa in the quadrants, a tendency to shorten major septa and a lack of half-phyllotheca in the ephebic stage are the main distinguishing characters of the new genus. (The term half-phyllotheca, introduced here, is applied to an arrangement of major septa wherein those of the counter quadrants, and sometimes also the oldest in the cardinal quadrants, are laterally in touch and form part of a tube, open towards a cardinal septum. The ends of major septa adjacent to the cardinal septum are disconnected).

Baritichisma Moore \& Jeffords, 1945, is the second genus closely related to Allotropiochisma n.gen. This is demonstrated first of all in its ontogeny, with slightly elongated protosepta, and in the tendency of septa to withdraw from a the corallite axis. The older part of the neanic stage of the new genus is especially similar to Baritichisma. Well developed pseudofossulae which result from the zaphrentoidal arrangement of septa, a lack of an allotropiophylloid stage of development, the different structure of the cardinal fossula which is bordered not by the two but by several successively shortened major septa, the slightly but permanently elongated counter septum and a lack of differentiation of the thickness of septa in quadrants, are the main characters distinguishing Baritichisma from the new genus.

Parastereophrentis Fomichev, 1953 is the next taxon which should be discussed as being similar or related to Allotropiochisma n.gen. Unfortunately, a lack of any species indicated as a type species for that subgenus invalidated it until Hill (1981) introduced $P$. virgata Fomichev, 1953, as its type species. Re-examination of Fomichev's (1953) specimens by the present author demonstrates the presence of a slightly elongated counter septum and major septa which are withdrawn from the corallite axis in the mature stage of the holotype of $P$. invalida Fomichev 1953. These characters bring the discussed species close to Baritichisma. On the basis of the type species chosen by her, Hill (1981) put Parastereophrentis into synonymy with Zaphrentites Hudson, 1941.

Specimens from Greenland assigned by Flügel (1973b) to Amplexizaphrentis differ in many details, but at the same time exhibit an adequate number of common or intermediate characters to be treated as members of Allotropiochisma n.gen. The specific concept of Flügel is not discussed in the present paper, partly because of the restricted number of specimens available for observation. Several additional sections of Flügel's specimens were prepared, however, to better expose the most important characters of the new genus. These, and some other sections are presented here for comparison (fig. 2.2a, b; Plate 4, figs 2-4). 


\section{Allotropiochisma birkenmajeri n.sp.}

Fig. 2.2a-g; Plate 4, fig. 1a-e

Holotype. MGUH 15.944 from GGU collection 230063.

Type locality. Freboldbjerg, locality 168 of Birkenmajer, 1976, Hold with Hope; height $260 \mathrm{~m}$ (see fig. 1).

Type horizon. Foldvik Creek Formation, Martinia Limestone Member.

Derivation of the name. In honour of Professor Krzysztof Birkenmajer, in recognition of his contribution to Arctic Geology.

Material. A single, almost complete specimen, with the uppermost part slightly flattened.

Diagnosis. Allotropiochisma with n:d ratio 32:22; major septa stop far from the corallite axis; minor septa elongated up to the length of majors.

Description. Early neanic stage (fig. 2.1g; Plate 4, fig. 1e): All major septa are thickened so as to be in contact with each other laterally; they do not reach the corallite axis but leave an irregular, free axial area $1.0 \times 0.5 \mathrm{~mm}$ in diameter. The cardinal and counter protosepta are slightly elongated while the alar prosepta are hardly recognisable. The cardinal septum lies in narrow, axially widened cardinal fossula, closed by a thickened section of tabula. Minor septa are not yet present in the corallite lumen.

Neanic stage (fig. 2.1e, f; Plate 4, fig. 1d): Two sides of the section which was made approximately $6 \mathrm{~mm}$ above the previously described one. The cardinal septum is already shortened and the counter septum does not differ from the counter-lateral septa. Elongation of the alar septa is especially well seen in fig. $2.1 \mathrm{f}$. Major septa of the cardinal quadrants are much longer and thinner than these of the counter quadrants. Minor septa penetrate the corallite lumen and are often contratingent. The stage described most resembles the late neanic stage of Baritichisma zaphrentiforme (White, 1876), redescribed by Sando (1965) and Weyer (1965). The counter septum, indistinguishable in length from other major septa, forms the only difference. The described stage of growth is also very closely comparable to the neanic stage of Allotropiochisma longiseptata (Flügel), illustrated on fig. 2.2a and Plate 4 , fig. $2 b$ in this paper.

Late neanic stage (fig. 2.1c, d; Plate 4, fig. 1b, c): Two sides of the section made $7 \mathrm{~mm}$ above the previously described one. Major septa are arranged almost radially, leaving a 3 mm wide free axial area. All of them, except for the thin and short cardinal septum are most thickened in the periaxial area, forming a wide, compact periaxial, phyllotheca-like ring. Axial ends of septa are not rounded, as observed in typically rhopaloid septa, but thin quickly and penetrate the axial area as sinuous tongues. The cardinal fossula is elongated, triangular in shape, and bounded by two major septa. In the ontogenetically younger stage (fig. $2.1 \mathrm{~d}$; Plate 4, fig. 1c) these septa are not longer than the neighbouring ones, and are united by a section of tabula. In the higher section (fig. 2.1c; Plate 4, fig. 1b) they are elongated, reaching the corallite axis. Minor septa adjacent to the counter septum are almost as long as major septa.

Ephebic stage (fig. 2.1a, b; Plate 4, fig. 1a): Major septa stop far short of the corallite axis, leaving a wide, free, axial area. They show slight thickening which is more prominent 
peripherally. The cardinal septum, which is very thin and shortened, lies in a hardly distinguishable cardinal fossula which is little different from normal septal loculi. The counter septum does not differ from the other major septa of the counter quadrants. Major septa on the lateral sides of the corallite are slightly elongated, but the alar protosepta are unrecognisable. Minor septa are either contratingent or free and show an irregular, but permanent, increase in length. At the base of the calice (fig. 2.1a), several of them are as long as the adjacent major septa, while others are comparatively short. Those adjacent to the counter septum are long, but are not inclined towards it. The external wall, septothecal in character, remains thin.

Remarks. The wide axial area free of septa and the very long minor septa are the most important distinguishing characters of this new species. Its mature stage differs greatly, not only from the type species of this genus, which has especially long septa, but also from other species. On the other hand, however, there are growth stages and developmental tendencies demonstrated by the investigated specimens which permit a close comparison with other species. In addition to the close similarity to the type species, seen in the neanic stage, the new species also demonstrates a close similariry to the holotype of $A$. exzentrica (Flügel) in the late neanic stage (Plate 4, figs $1 b, c ; 3 b$ ). The ephebic stage of the latter is slightly different (Plate 4, fig. 3a), but it differs also from the paratype of this species (Plate 4, fig. 4a) which shows a tendency to shorten the major septa. The last two sections are new sections made from Flügel's (1973b) specimens. It is noteworthy that the youngest preserved stage of the paratype of $A$. exzentrica (Plate 4, fig. 4b) closely resembles the mature part of the holotype of $A$. longiseptata. The interrelationships of individual specimens discussed here, and their ontogeny, demonstrate not only the close relation of the new species to the group of Flügel's (1973b) species, but also the complex nature of the genus.

Occurrence. Hold with Hope, Martinia Limestone Member, Foldvik Creek Formation, Upper Permian.

\section{The coral thanatocoenosis in the Posidonia Shale Member}

All the specimens collected from the Posidonia Shale Member possess septa which are thickened at least in the neanic stage. Their external walls are thick and bear more or less well developed epithecal spines. The latter follow the indistinct growth rings and almost invariably form vertical rows. Longer spines are commonly directed slightly downwards, although spines perpendicular to the corallite surface are also common. The development of spines, the thickened lower portions of corallites and the deep, comparatively light calices are interpreted here as adaptations to development on a soft muddy bottom with no algal mat. All these characters help the unattached specimens to keep balance in mud. None of the observed specimens shows any kind of attaching processes or talons, but well preserved corallites possess naked tips (Plate 4, fig. 5). The occurrence of these tips might have been a reproductory adaptation similar to that described by Minato \& Rowett (1968) for Timania rainbowensis, Rowett, 1969. This seems quite probable in the habitat under discussion, where no possibilities existed for larvae to attach themselves to the muddy bottom.

None of the examined specimens show changes in growth direction of the type characteristic of corallites which have continued their growth after having been tilted over. This is perhaps because they were not adapted for sediment rejection in a similar manner to that 
observed in several recent scleractinians (Hubbard \& Pocock, 1972). Deep, narrow calices and smooth septa confirm this supposition.

The characteristics of the described corals suggest that any disturbance in the mud balance was probably fatally dangerous for them. Perfectly adapted to the deep, well protected sea bottom with very small rates of sedimentation and with almost no water movements, they almost certainly reacted immediately to any changes in the environment. Although their heavy tips would help them to maintain their life position after a minor disturbance, any stronger action would have caused their burial and death in the clogging mud.

The preserved position in the rock does not represent the growth position of the coral fauna. All specimens rest more or less parallel to shale surfaces. They are often parallel to each other (Plate 2, fig. 8), but are not necessarily oriented in accordance to their growth directions. In all cases, both the direction of curvature of individual specimens and the direction of development of spines indicates their preserved position in the rock is not identical with their life position. Some have possibly been transported and have accumulated in agglomerations (Plate 2, fig. 8). Others may have only fallen over on their side and thus remain more or less in the place where they lived.

It seems very probable that a delicate balance existed between the unconsolidated mud and the corals which lived half-suspended in it. Any small movement of mud, caused by deep wave activity generated, for example, by storms, mud slides, or any other phenomena disturbing the mud balance would produce local or more general destruction and burial of coral communities. Although only short transport of the corals, or falling over from their life position, is suspected, transport over longer distances in mud flows or slides, without any traces of rounding, abrasion or destruction, is possible.

Acknowledgements. I wish to express my thanks to K. Birkenmajer (Institute of Geology of the Polish Academy of Sciences, Cracow) for offering me his interesting collection for study and to S. Floris (Geological Museum, Copenhagen) for sending me several of Flügel's (1973b) specimens for comparison and re-examination. Miss. M. Szyprowska prepared peels and thin sections and A. Pietura took the photographs. MMH and MGUH denote specimens in the type collection of the Geological Museum, Copenhagen. Additional non-figured material is in the collections of the Geological Survey of Greenland.

\section{References}

Birkelund, T. \& Perch-Nielsen, K. 1976: Late Palaeozoic - Mesozoic evolution of central East Greenland. In Escher, A. E. \& Watt, W. S. (edit.) Geology of Greenland, 305-339. Copenhagen: Geol. Surv. Greenland.

Birenheide, R. \& Soto, F. M. 1977: Rugose corals with wall-free apex from the Lower Devonian of the Cantabrian Mountains, Spain. Senckenberg. Leth. 58, 1-23.

Flügel, H. W. 1973a: Zur Kenntnis der Typus von Calophyllum Dana, 1846: Turbinolia donatiana King, 1848 (Anthozoa). N. Jb. Geol. Paläont. Min. 2, 61-66.

Flügel, H. W. 1973b: Rugose Korallen aus dem oberen Perm Ost-Grönlands. Verh. Geol. B.-A 1973, 1, 1-57.

Fomischev, V. D. 1953: Korally Rugosa i stratigrafiya sredne - i verkhnekamennougolnykh i permskikh otlozhenyi Doneckogo Basseina. Trudy vses. nauchno-issled. geol. Inst. Gosgeolizdat. 622 $\mathrm{pp}$.

Grabau, A. W. 1928: Palaeozoic corals of China. Part I. Tetraseptata. Palaeont. Sinica B, 2(2), 175 pp. 
Hill, D. 1981: Coelenterata. Supplement 1, Rugosa and Tabulata. In R. C. Moore (edit.) Treatise on Invertebrate Paleontology F, 762 pp. Lawrence: Kansas U.P.

Hubbard, J. A. E. B. \& Pocock, Y. P. 1972: Sediment rejection by recent scleractinian corals: a key to palaeo-environmental reconstruction. Geol. Rundschau 61(2), 598-626.

Ivanovsky, A. B. 1972: Vnutrividovaya izmenchivost, morfologiya i ontogenez skeleta Calophyllum profundum (Rugosa). Trudy Inst. Geol. Geofiz. 112, 4-9.

Kato, M. 1963: Fine skeletal structures in Rugosa. J. Fac. Sci. Hokkaido Univ. 4(11), 571-630.

Kunth, A. 1869: Beiträge zur Kenntnis fossiler Korallen. Zeischr. Deutsch. geol. Ges. 21, 647-688.

Minato, M. \& Rowett, C. L. 1968: Modes of reproduction in rugose corals. Lethaia 1, 175-183.

Sando, W. J. 1965: Revision of some Paleozoic coral species from the Western United States U.S. geol. Surv. Prof. Pap. 503-E, 36 pp.

Schindewolf, O. H. 1942: Zur Kenntnis der Polycoelien und Plerophyllen. Abh. Reichamts Bodenforschung 204, $324 \mathrm{pp}$.

Soshkina, E. 1925: Les coraux du Permien inférieur (étage d'Artinsk) du versant occidental de l'Oural. Bull. Soc. Natur. Moscou n.s. 33, 76-104.

Soshkina, E. 1928: Nizhnepermskie (artinskie) korally zapadnogo sklona Severnogo Urala. Bull. Soc. Natur. Moscou n.s. 36, 339-393.

Soshkina, E., Dobrolyubova, T. \& Porfiriev, G. 1941: Permskie Rugosa evropeyskoi chasti SSSR. Paleontologia SSSR 5, 3, 1, 1-304.

Weyer, D. 1965: Über Amplexus zaphrentiformis White, 1876 (Pterocorallia; Oberkarbon, Pennsylvanian). Geologie 14, 449-463. 


\section{Plate 1}

Calophyllum profundum (Geinitz, 1842). All specimens came from Wegener Halvø, Posidonia Shale Member, Foldvik Creek Formation, Upper Permian. All figures, $\times 5$.

Fig. 1. MGUH 15.945 from GGU ccllection 229902. a, lower part of calice; b, just beneath calice; c, early ephebic or late neanic stage; $d$, neanic stage.

Fig. 2. MGUH 15.946 from GGU collection 229902. a, b, successive sections across calice; c, beneath calice; d, late neanic stage.

Fig. 3. MGUH 15.947 from GGU collection 229902. a, middle part of calice; b, just above calice bottom; $c$, just below calice bottom; d, e, early ephebic stage; $f$, neanic stage.

Fig. 4. MGUH 15.948 from GGU collection 229902. a, b, ephebic stage; c, late neanic stage.

Fig. 5. MGUH 15.949 from GGU collection 229902. a, ephebic stage; b, neanic stage.

Fig. 6. MGUH 15.950 from GGU collection 229903. a, lower part of calice; b, partly below (upper side), partly above (lower side) bottom of calice; c, late ephebic stage; $d$, neanic stage.

Fig. 7. MGUH 15.951 from GGU collection 229903, ephebic stage.

Fig. 8. MGUH 15.952 from GGU collection 229903, ephebic stage. 

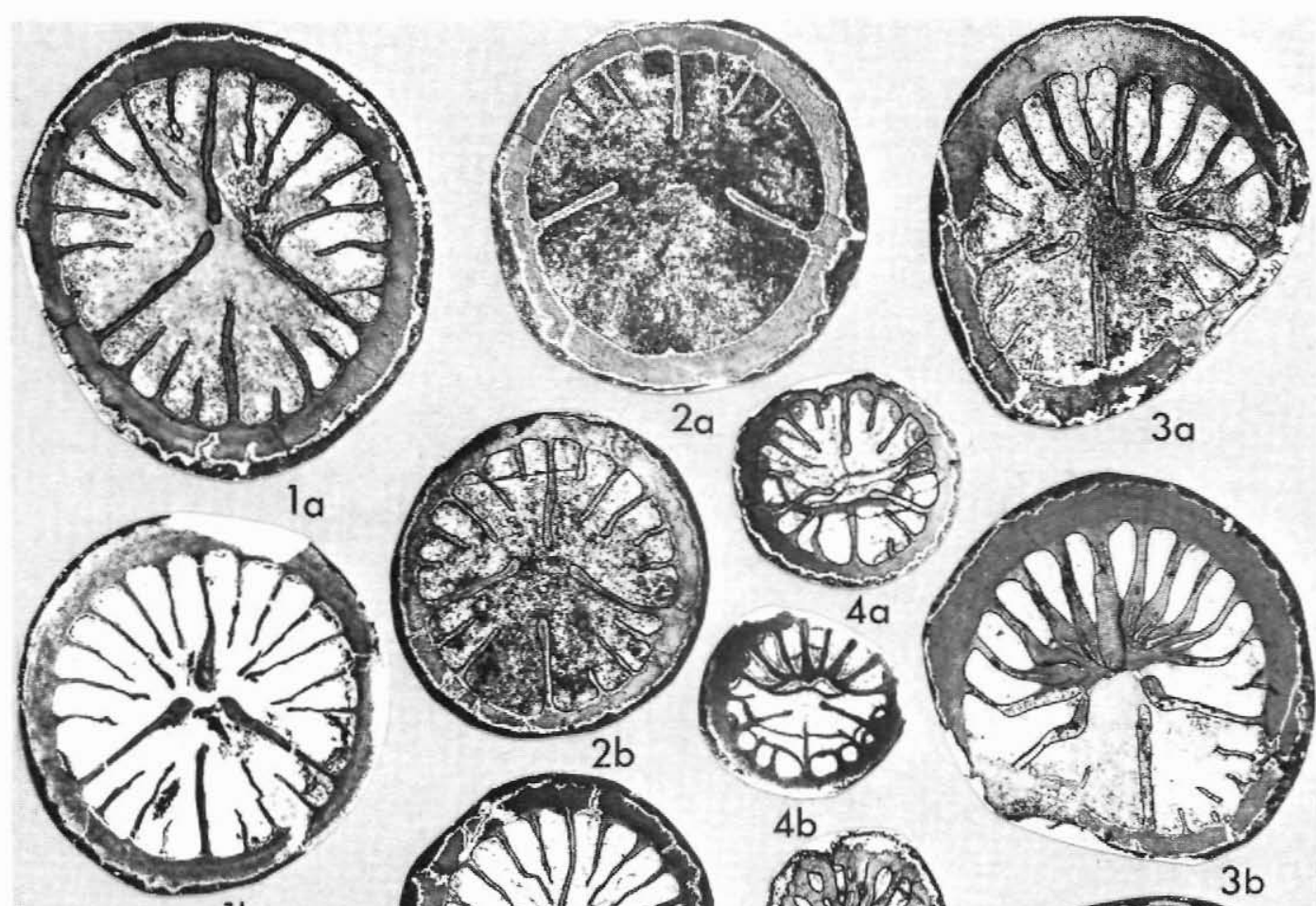

Ib
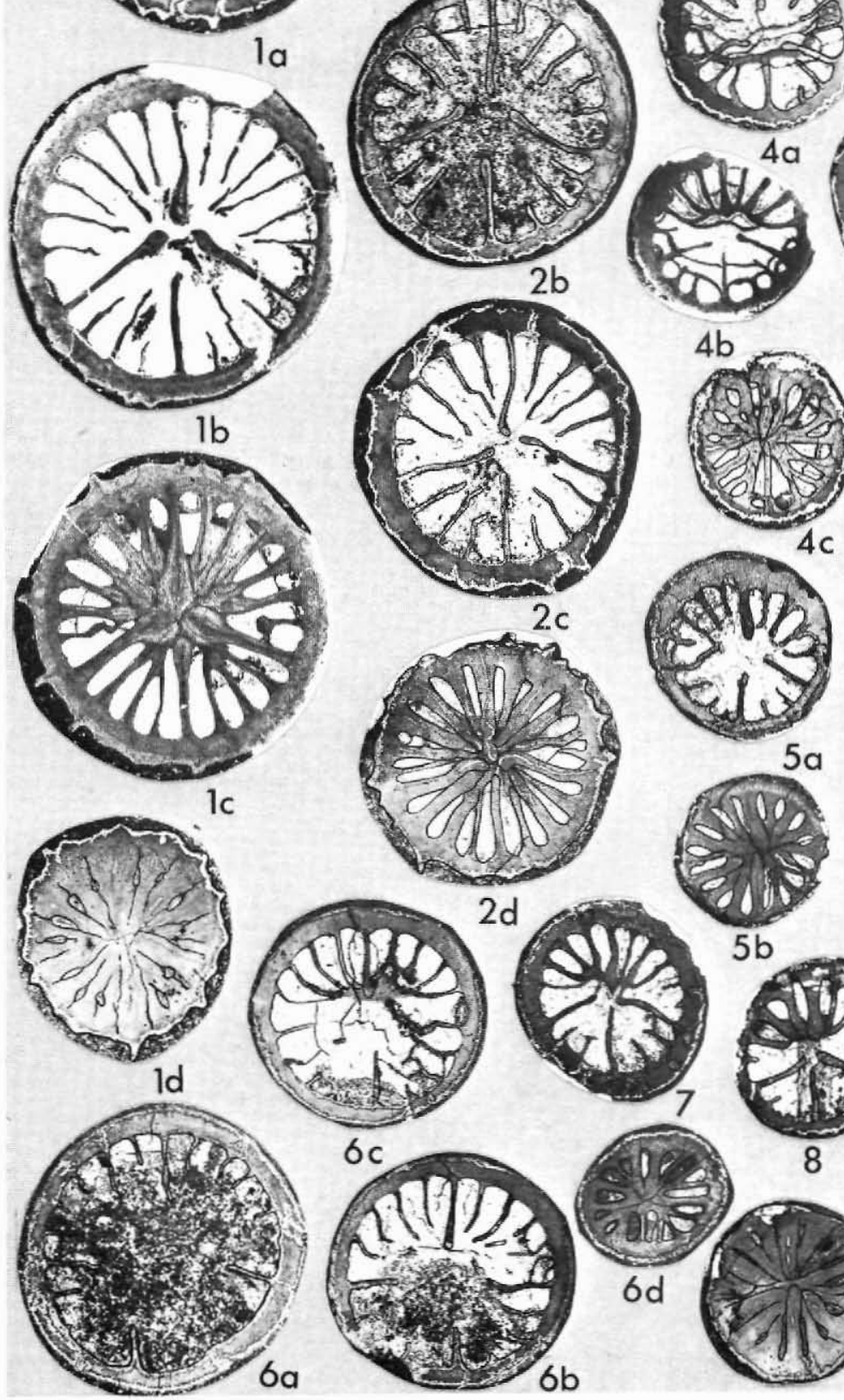

$5 b$
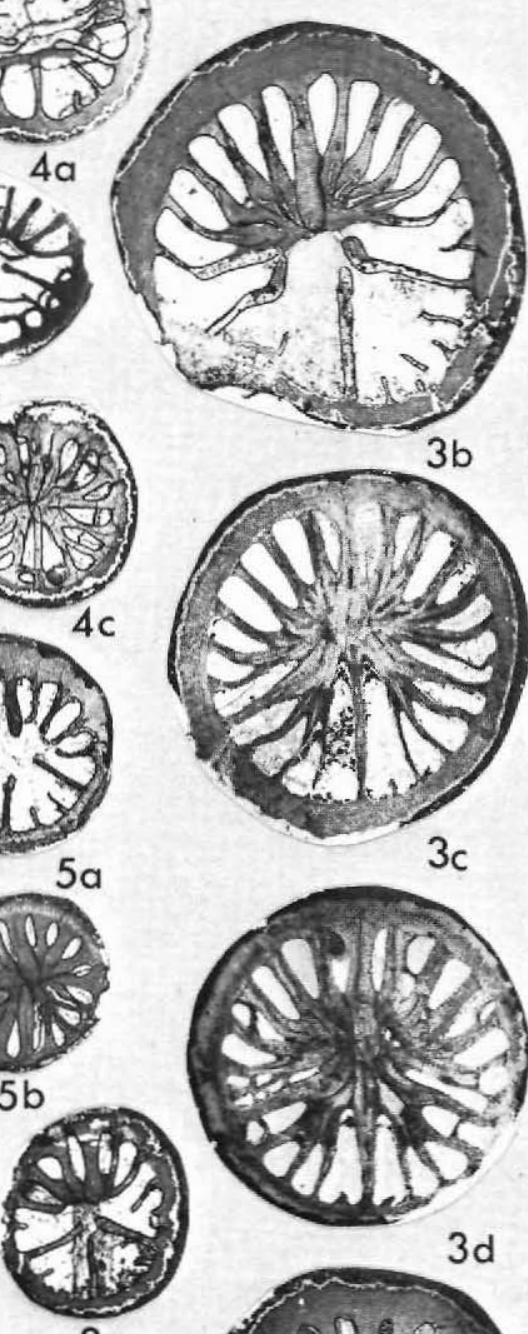
ex $1: \rightarrow$
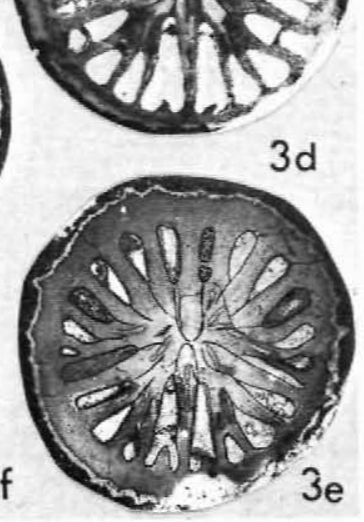


\section{Plate 2}

Calophyllum profundum (Geinitz, 1842). All specimens except for fig. 1 came from Wegener Halvø, Posidonia Shale Member, Foldvik Creek Formation, Upper Permian. Fig. $8, \times 3$, all other figures, $\times 5$.

Fig. 1. MMH 11.933, holotype of C. (G.) nodosum Flügel, 1973. Kap Stosch, Productus Limestone Member, Upper Permian. a, b, ephebic stage. Section 1b illustrated by Flügel, 1973b, fig. 7C.

Fig. 2. MGUH 15.953 from GGU collection 229903. a, ephebic stage; b, early ephebic or late neanic stage.

Fig. 3. MGUH 15.954 from GGU collection 229902. a, ephebic stage just beneath calice; b-e, successive sections of ephebic stage; $f$, late neanic stage.

Fig. 4. MGUH 15.955 from GGU collection 229902. a, b, successive sections of ephebic stage.

Fig. 5. MGUH 15.956 from GGU collection 229903, ephebic stage.

Fig. 6. MGUH 15.957 from GGU collection 229903. a, middle part of calice; b, across calice bottom; c, ephebic stage.

Fig. 7. MGUH 15.958 from GGU collection 229902. a, middle part of calice; b, ephebic stage; c, neanic stage.

Fig. 8. Transported assemblage of specimens showing variation in morphology and in size. GGU collection 229902. 


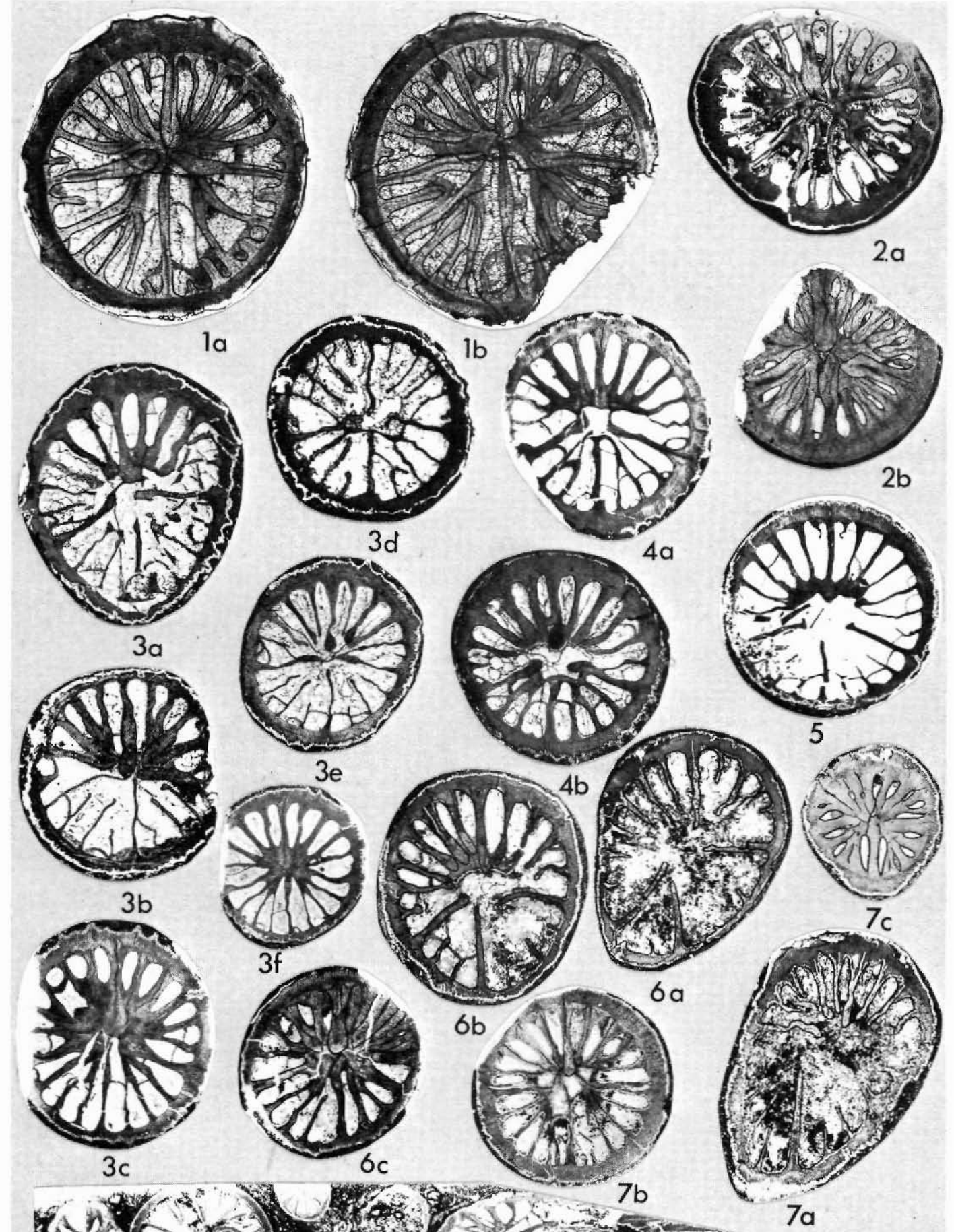

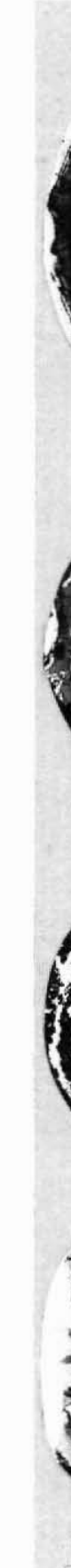




\section{Plate 3}

Fig. 1. Calophyl um profundum (Geinitz, 1842). MGUH 15.959 from GGU collection 229902. Wegener Halvø, Posidonia Shale Member, Foldvik Creek Formation, Upper Permian. Ephebic stage, $\times 5$.

Fig. 2. Calophyllum profundum (Geinitz, 1842). MGUH 15.960 from GGU collection 229904. Hold with Hope, Productus Limestone Member, Foldvik Creek Formation, Upper Permian. a, b, ephebic stage, $\times 3$; c, neanic stage, $\times 3$.

Fig. 3. Tachylasma rhizoides Soshkina, 1925. MMH 11.937, holotype of C. (T.?) irregulare Flügel, 1973 Kap Stosch, Productus Limestone Member, Upper Permian. a, b, ephebic stage (newly made sections); $\mathrm{c}$, d, late neanic stage, $\times 3$ (section $3 \mathrm{c}$ illustrated by Flügel, 1973b, fig. 10B); e, f, neanic stage, $\times 5$ (section $3 \mathrm{f}$ illustrated by Flügel, 1973b, fig. 10A).

Fig. 4. Tachylasma rhizoides Soshkina, 1925. MMH 11.943. Locality as above. a, bottom of calice, $\times 2$; b, approximately $7 \mathrm{~mm}$ below calice, late neanic stage (section illustrated by Flügel, 1973b, fig. 13E).

Fig. 5. Tachylasma rhizoides Soshkina, 1925. MGUH 15.961 from GGU collection 230063. Hold with Hope, Martinia Limestone Member, Foldvik Creek Formation, Upper Permian. Neanic stage $\times 5$.

Fig. 6. Calophyllum profundum (Geinitz, 1842). MGUH 15.962 from GGU collection 229904. Hold with Hope, Productus Limestone Member, Foldvik Creek Formation, Upper Permian. Section across calice, $\times 3$.

Fig. 7. Calophyllum profundum (Geinitz, 1842). MGUH 15.963 from GGU collection 229904. Locality as above. Section across lower part of calice, $\times 3$. 

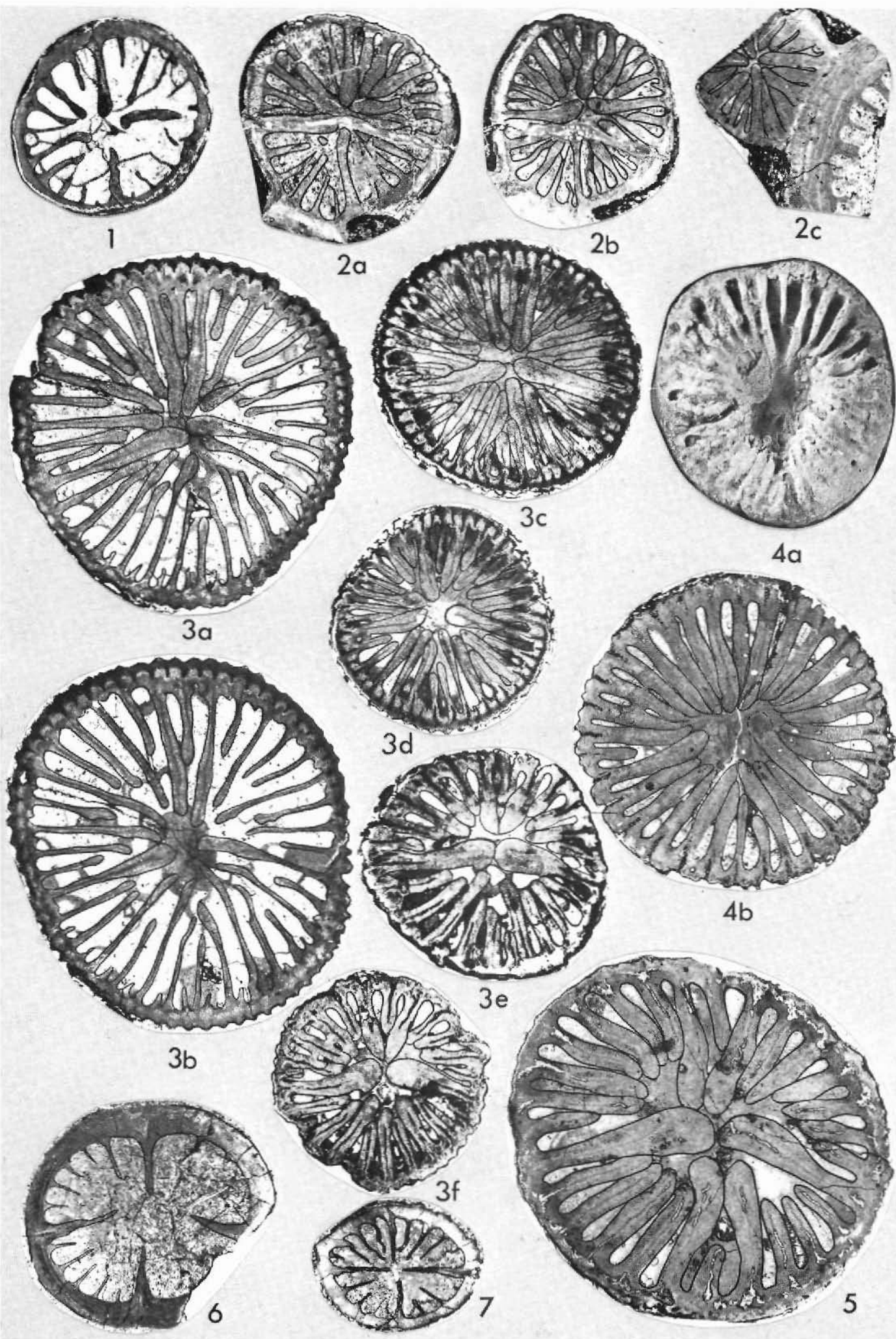


\section{Plate 4}

Fig. 1. Allotropiochisma birkenmajeri n.sp. Holotype, MGUH 15.944 from collection 230063. Hold with Hope, Martinia Limestone Member, Foldvik Creek Formation, Upper Permian. a, ephebic stage, $\times 2$; b, c, late neanic stage, $\times 3$; d, neanic stage, $\times 5$; e, early neanic stage, $\times 5$.

Fig. 2. Allotropiochisma longiseptata (Flügel, 1973). MMH 11.948, holotype. Kap Stosch, Productus Limestone Member, Upper Permian. a, ephebic stage, $\times 3$ (section illustrated by Flügel, 1973b, fig. 18 ); b, c, neanic stage, $\times 5$ (newly made sections).

Fig. 3. Allotropiochisma exzentrica (Flügel, 1973). MMH 11.945, holotype. Kap Stosch, Productus Limestone Member, Upper Permian. a, ephebic stage, $\times 3$ (newly made section); $b$, late neanic stage, $\times$ 3 (section illustrated by Flügel, 1973b, fig. 15).

Fig. 4. Allotropiochisma exzentrica (Flügel, 1973). MMH 11.946, paratype. Locality as above. a, ephebic stage, $\times 2$ (newly made section); $b$, late neanic or early ephebic stage, $\times 2$ (section illustrated by Flügel, 1973b, fig. 16).

Fig. 5. Calophyllum profundum (Geinitz, 1842). MGUH 15.964 from GGU collection 229903. Wegener Halvø, Posidonia Shale Member, Foldvik Creek Formation, Upper Permian. Naked tip of specimen showing originally rounded peripheral parts of two protosepta. 

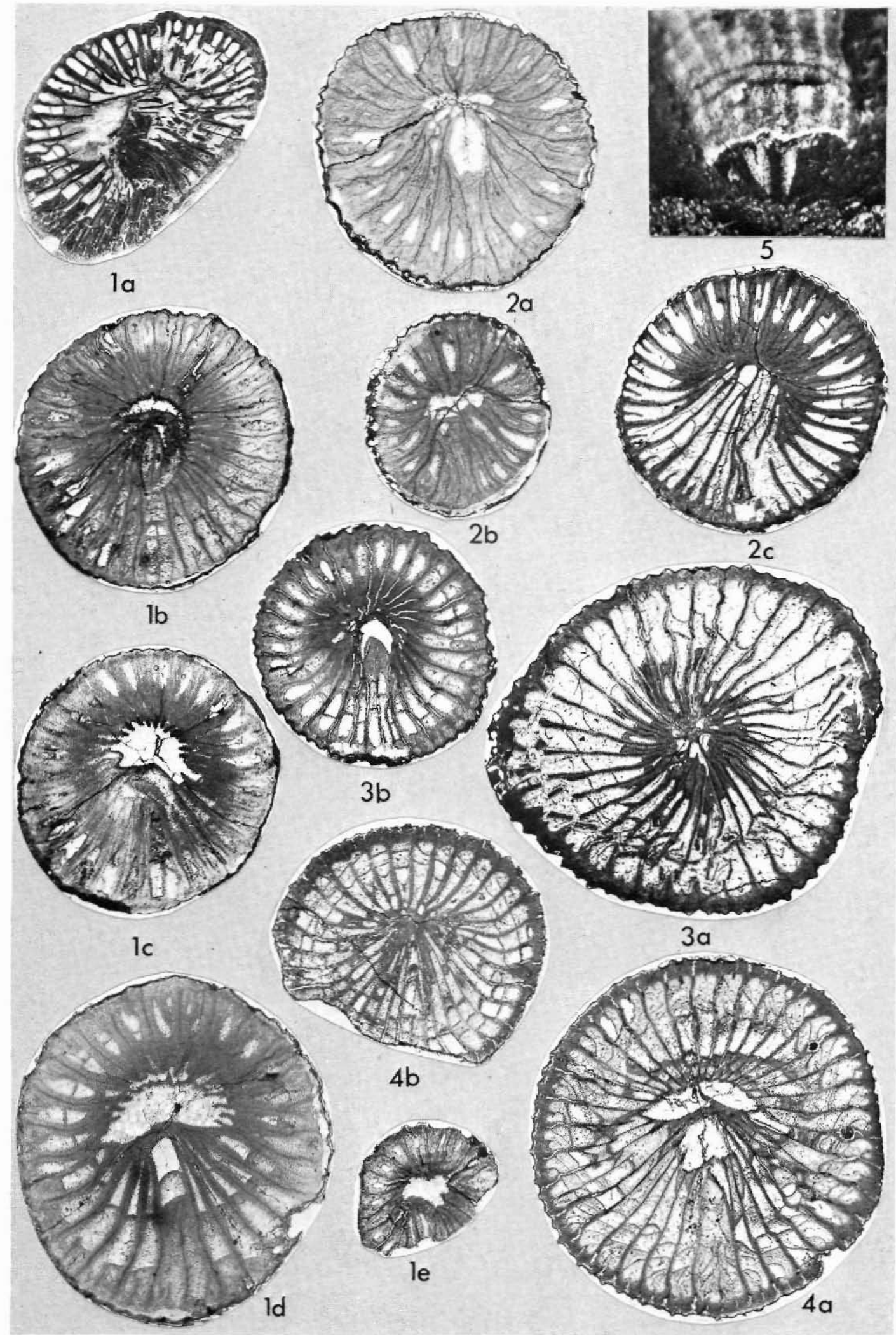